\title{
EKSPLOITASI KESALAHAN KONSEP TEORI GRAF DALAM Perkuliahan Matematika Diskrit Menggunakan Metode GaMe "Tantangan BERHADiaH POINT"
}

\author{
EXPloiting CONCEPT ERROR OF GRAPH THEORY IN DiSCRETE MATHEMATICS \\ courses Using Game Method " Tantangan Berhadiah Point"
}

\author{
Dian Mardiani \\ Program Studi Pendidikan Matematika, STKIP Garut \\ Garut, Jawa Barat, Indonesia \\ alfid51@yahoo.com
}

\begin{abstract}
Abstrak
Tujuan dari penelitian ini adalah untuk mengetahui kesalahan konsep teori graf apa saja yang dapat terjadi ketika game "tantangan berhadiah point" diterapkan dalam perkuliahan matematika diskrit dengan tema sejarah dan teori graf. Subjek penelitian dari penelitian ini adalah kelas 2B Prodi Pendidikan Matematika tahun ajaran 2016/2017 berjumlah 34 mahasiswa. Penelitian ini merupakan penelitian deskriptif. Hasil analisa data penelitian ini, ditemukan ada tujuh jenis kesalahan yang terjadi. Mahasiswa salah mengingat dalam menulis nama tokoh sejarah atau nama tempat dalam sejarah graf sebanyak $68 \%$, kemudian $35 \%$ mahasiswa salah dalam menulis simbol derajat dari suatu simpul, $18 \%$ salah dalam memahami konsep derajat suatu simpul pada graf, $18 \%$ salah dalam memahami konsep sisi dan simpul pada graf, $15 \%$ mahasiswa salah dalam proses berhitung, 3\% salah dalam mengingat informasi, $24 \%$ mahasiswa salah memahami konsep derajat dari graf yang mengandung loop. Dari survey diperoleh $88 \%$ mahasiswa memberikan pendapat positif terhadap game ini, walaupun hanya $9 \%$ yang berhasil menjawab sempurna semua soal tes. Kesimpulannya game ini tidak menjamin efektifitas perkuliahan namun memberikan suasana belajar yang lebih positif.

Kata Kunci: game, teori graf, tantangan berhadiah point.
\end{abstract}

\begin{abstract}
The purpose of this study is to find out mistakes in learning Graph theory while applying the concept with games "Challenge made point" in Diskrit Math lecturing with theme: Story and Graph Theory. Subjects of this study are 34 students of Math Program class 2B year 2017-2018. This descriptive study found that there are seven mistakes occurred. Some students were false to remember in writing the name of Math expert or the name of history place of Graph theory about $68 \%$, meanwhile $35 \%$ students were false to write symbol degree concept from a knot of Graph, $15 \%$ students were false in counting process, $3 \%$ students were false to remember information, and $24 \%$ students were false to understand degree concept of Graph had loop. Meanwhile, from survey, it found that $88 \%$ students gave positive response toward this game, although only $9 \%$ student's success to answer the test perfectly. The main point is, this game didn't ensure effective lecturing, but it made more positive atmosphere while teaching and learning process.

Keyword: Game, Graph theory, Challenge made point.
\end{abstract}

\section{Pendahuluan}

Menurut Hamalik (2003) "Belajar adalah suatu proses, suatu kegiatan dan bukan suatu hasil dan tujuan." Awalnya peneliti dalam upaya membelajarkan suatu sejarah graf akan memilih metode 
ceramah. Namun peneliti berpikir dengan metode ceramah akan terasa monoton dan membosankan, sehingga dikhawatirkan mahasiswa tidak merasa tertantang untuk belajar teori graf yang saat ini berkembang seiring banyaknya manfaat dari teori ini dalam kehidupan sehari-hari. Pertemuan pertama perkuliahan teori graf akan berdampak kepada pertemuan-pertemuan berikutnya. Tujuan perkuliahan ini tentu bukan sekedar untuk mentransfer pengetahuan, melainkan harus ada membangkitkan keinginan dan kemampuan mahasiswa dalam belajar dan mendalami teori graf secara mandiri dan berkelanjutan, sehingga mahasiswa melakukan suatu proses kegiatan yang namanya belajar. Usaha membangkitkan keinginan dan kemampuan mahasiswa dalam belajar dan mendalami teori graf secara mandiri penting diupayakan. Berdasar hasil penelitian (Dian: 2001) kesamaan karakteristik gaya belajar matematika siswa berprestasi dari tipe visual, auditorial, dan kinestik menunjukkan bahwa siswa berprestasi memiliki kemandirian dalam belajar matematika terutama dalam berlatih soal-soal matematika. Sigit Wahyudi (1995:77) menyatakan bahwa berdasar hasil penelitiannya ada korelasi positif yang signifikan antara kemandirian dalam belajar dengan prestasi belajar. Hal ini merupakan bukti bahwa kemandirian belajar teori graf cukup berperan penting dalam mencapai prestasi yang tinggi dalam belajar teori graf. Untuk memperoleh hasil belajar yang sesuai harapan, peneliti memilih metode game "tantangan berhadiah point". Namun peneliti belum pernah mengkaji bagaimana hasil belajar dengan metode ini. Sehingga pada tulisan kali ini rumusan masalah penelitian yang diangkat adalah kesalahan konsep teori graf apa saja yang dapat terjadi ketika game "tantangan berhadiah point" diterapkan dalam perkuliahan matematika diskrit dengan tema sejarah dan teori graf? Tujuan penelitian ini adalah untuk mengetahui kesalahan konsep teori graf apa saja yang dapat terjadi ketika game "tantangan berhadiah point" diterapkan dalam perkuliahan matematika diskrit dengan tema sejarah dan teori graf. Manfaat dari penelitian ini bagi penulis untuk mengkaji metode perkuliahan sehingga di tahun berikutnya dapat menyajikan perkuliahan teori graf dengan lebih efektif dan bermakna. Harapan penulis minimal mahasiswa mendapat pengalaman berbeda, metode perkuliahan yang variatif, atau dan memperoleh pembelajaran yang lebih bermakna dibanding dengan metode ceramah.

Burton mengusulkan dalam (Tim MKPBM Jurusan Pendidikan Matematika: 2001) bahwa tanggung jawab guru dalam proses belajar adalah untuk menstimulasi dan memotivasi siswa, menyediakan pengalaman untuk menumbuhkan pemahaman, mendiagnosa dan mengatasi kesulitan siswa, dan mengevaluasi. Banyak metode pembelajaran matematika yang dapat di pilih untuk memenuhi tanggung jawab itu, di antaranya: metode ceramah, 
metode ekspositori, metode drill, metode demonstrasi, metode tanya jawab, metode penemuan, metode inkuiri, metode permainan dan metode pemberian tugas (Tim MKPBM Jurusan Pendidikan Matematika: 2001). Menurut Daryanto dalam (Ari: 2016) pendidik berkewajiban membangkitkan motivasi siswa sehingga ia mau melakukan belajar.

Permainan matematika diharapkan dapat menjadi kegiatan menggembirakan yang dapat menunjang tercapainya tujuan intruksional matematika dalam aspek kognitif, afektif, dan psikomotor sehingga dapat meningkatkan motivasi belajar, keterampilan pemahaman konsep, dan pemantapannya. Pada penelitian ini, untuk perkuliahan Matematika Diskrit dengan tema sejarah dan teori graf dipilih game "tantangan berhadiah point". Berikut adalah langkah-langkah game "tantangan berhadiah point" :

1. Menugaskan mahasiswa untuk membaca terlebih dahulu materi yang akan disampaikan dengan metode game, di rumah. Ini di sosialisasikan di pertemuan sebelumnya.

2. Sebelum perkuliahan berlangsung, jika banyak mahasiswa mengabaikan tugas tersebut, karena biasanya ada saja mahasiswa yang tidak melaksanakan tugas seperti itu. Beri waktu sekitar 30 menit atau sesuai keperluan untuk memaksa mahasiswa mau membaca teori sebelum dijelaskan dan siap mempresentasikan hasil belajarnya, karena mereka akan menghadapi game "tantangan berhadiah point". Jelaskan aturan main game sehingga mereka mau dan berusaha belajar secara mandiri dalam waktu yang disediakan.

3. Setelah semua siap, berikan tantangan pertama, lalu kocok nama mahasiswa secara acak. Yang terpilih, maju ke depan, menjelaskan hasil belajarnya sedetail mungkin, sehingga point yang diperoleh maksimal. Mahasiswa yang tidak terpilih, memperhatikan penjelasan temannya di depan, boleh sambil membuka buku sumber, dan menghitung berapa fakta yang benar dari yang dijelaskan, jumlah fakta benar yang disampaikan, adalah hadiah point bagi temannya.

4. Jika ada yang memberikan tambahan informasi bagi tantangan 1, dan diperkenankan, maka mahasiswa tersebut mendapat point 1

5. Jika tantangan 1 sudah cukup, lanjut ke tantangan berikutnya, sehingga langkah 3,4,5 terus berulang sampai waktu yang ditentukan untuk game berakhir.

6. Langkah terakhir adalah melakukan tes hasil belajar pertemuan tersebut, sehingga dapat diketahui ada tidaknya kesalahan dalam pemahaman konsep teori graf. Bahan untuk di luruskan di pertemuan selanjutnya sebelum ke tema berikutnya. 
Langkah pertama dalam game ini yaitu menugaskan mahasiswa untuk membaca terlebih dahulu materi yang akan disampaikan dengan metode game, di rumah dan di sosialisasikan di pertemuan sebelumnya. Tujuannya adalah untuk memberikan kesempatan mahasiswa melakukan proses belajar mandiri dalam mencari, mengetahui fakta-fakta sejarah graf dan memahami konsep-konsep baru berkenaan teori graf, sebanyakbanyaknya. Di kelas, dosen bisa mengetahui apakah langkah ini dilakukan oleh semua mahasiswa, jika tidak, langkah kedua dengan tujuan yang sama, harus dilakukan. Dosen perlu memberi motivasi efektif supaya mahasiswa dengan rela ataupun terpaksa melakukan langkah kedua yaitu mahasiswa mau membaca teori sebelum dijelaskan dan siap mempresentasikan hasil belajarnya. Dalam hal ini, semua mahasiswa memiliki buku sumber belajar, dan juga dapat mencari sumber lainnya.

Langkah ketiga bertujuan untuk memberi kesempatan kepada beberapa mahasiswa untuk mengkomunikasikan hasil belajarnya di langkah 2. Pada langkah 3 ini, tujuan utama adalah melatih kemampuan komunikasi matematis mahasiswa. Kemampuan ini penting untuk dilatihkan. Hulukati dalam (Asep Saepuloh, 2013) menyatakan bahwa kemampuan komunikasi matematis siswa sangat penting dikembangkan pada proses pembelajaran karena kemampuan ini merupakan syarat untuk memecahkan masalah. Mengapa dalam langkah ketiga nama mahasiswa yang harus melakukan tantangan dipilih secara acak? Ini adalah untuk memaksa semua mahasiswa belajar sungguh sungguh di tahap 2, karena permainan ini bersifat individual. Selain itu, supaya tidak ada perasaan bahwa dosen menganak tirikan ataupun menganak emaskan beberapa dari subjek menjelaskan hasil belajarnya sedetail mungkin, sehingga point yang diperoleh maksimal. Mahasiswa yang tidak terpilih, memperhatikan penjelasan temannya di depan, boleh sambil membuka buku sumber, dan menghitung berapa fakta yang benar dari yang dijelaskan, jumlah fakta benar yang disampaikan, adalah hadiah point bagi temannya. Tujuan dari ini, supaya perhatian semua mahasiswa kepada teman yang sedang mengkomunikasikan pengetahuannya dalam taraf baik, sehingga yang di depan, merasa dihargai dan menerima pengalaman positif. Bagi mahasiswa pendengar, pun dapat melatih kemampuannya dalam melakukan evaluasi. Langkah 4, bertujuan sama dengan langkah 3.

Konsep teori graf yang dibelajarkan dengan game "tantangan berhadiah point" meliputi sejarah graf, definisi graf, konsep simpul dan sisi pada graf, graf sederhana, graf ganda, graf semu, derajat dari suatu simpul dan simpul terpencil pada graf tak berarah, konsep derajat dari simpul pada graf berarah.

Berikut tantangan-tantangan yang dimainkan dalam game ini:

1. Ngadongeng sejarah graf 
2. Jelaskan definisi graf (termasuk menjelaskan istilah simpul, sisi, juga contoh graf)

3. Jelaskan graf sederhana, graf ganda, dan graf semu

4. Jelaskan konsep derajat suatu simpul, simpul terpencil dari graf tak berarah

5. Jelaskan konsep derajat suatu simpul, simpul terpencil dari graf berarah.

\section{Metode}

Penelitian ini merupakan suatu penelitian deskriptif. Subjek penelitian dari penelitian ini adalah kelas 2B Prodi Pendidikan Matematika tahun ajaran 2016/2017 berjumlah 34 mahasiswa. Instrumen penelitian ini berupa lembar pengamatan, angket dan tes. Lembar pengamatan bertujuan untuk menuliskan hasil pengamatan terhadap mahasiswa selama proses belajar berlangsung. Angket untuk mengetahui pendapat mahasiswa tentang game ini. Sedangkan tes yang diberikan setelah game berakhir, untuk mengetahui apakah mahasiswa mampu mengingat beberapa hal tentang sejarah graf, beberapa konsep teori graf yang telah dia pelajari secara mandiri juga telah dijelaskan mahasiswa terpilih ketika game berlangsung.

\section{Hasil dan Pembahasan}

Berdasar hasil pengamatan, di tahap 2, nampak semua mahasiswa bersungguhsungguh berusaha membaca, memahami, dan menghapal setiap informasi yang akan dijadikan bahan tantangan dalam game. Di proses ini, beberapa mahasiswa aktif berdiskusi dan saling melengkapi pemahaman masing-masing. Mereka fokus belajar dan diskusi sampai menambah waktu untuk lebih siap dalam game. Hal ini sesuai harapan, mahasiswa melakukan belajar secara mandiri, menggunakan sumber-sumber belajar yang mereka miliki, dan malakukan pula diskusi yang baik dalam latihan pengembangan kemampuan berkomunikasi secara verbal.

Pada tahap 3, ketika tantangan pertama dibacakan yaitu mendongeng sejarah graf. Semua memperhatikan penjelasan dari teman terpilih, memberikan pertanyaan, dan tambahan informasi, serta pemberian point, sehingga proses ini tidak berkesan tegang, tapi juga semua memperhatikan. Dan begitu pula yang terjadi di tantangan kedua, ketiga dan seterusnya.

Mahasiswa sebanyak $68 \%$ salah mengingat dalam menulis nama tokoh sejarah atau nama tempat dalam sejarah graf. Ini kesalahan yang paling banyak terjadi. Kemungkinan besar, mahasiswa tidak menyangka bahwa dalam tes akan dipertanyakan tentang nama tokoh tersebut, yang memang penulisannya cukup tak mudah dihafal bagi orang Indonesia. Tetapi, kesalahan ini, dapat membuat kesan mendalam, sehingga mereka akan lebih ingat ke depannya bagaimana cara menuliskan nama tokoh tersebut.

Pada tahap terakhir, pemberian tes, mahasiswa menjawab setiap pertanyaan secara tertulis, sesuai kemampuan sendiri. 
Dan mereka diberi pula angket untuk memberikan masukan berupa kesan dan kritikan terhadap pembelajaran dengan game "tantangan berhadiah point". Hasil dari angket ini dan pula hasil tes, menunjukkan bahwa $88 \%$ mahasiswa memberikan pendapat positif terhadap game ini, walaupun hanya 9\% yang berhasil menjawab sempurna semua soal tes. Kesimpulannya game ini tidak menjamin efektifitas perkuliahan namun memberikan suasana belajar yang lebih positif. Walau tidak menjamin efektifitas perkuliahan, dalam hal ini mahasiswa mendapat nilai sempurna dalam hasil evaluasi, namun tidak ada kesan hanya menghamburkan waktu, dan tidak mengganggu ketenangan belajar kelaskelas lain. Tim MKPBM Jurusan Pendidikan Matematika (2001) menyatakan dalam menggunakan metode permainan, hindari kelemahan dari metode ini di antaranya terkesan menghamburkan waktu dan mengganggu ketenangan belajar di kelaskelas lain.

Berdasar hasil tes, hasil penelitian ini dapat dilihat pada tabel berikut:

Tabel 1.

Jenis Kesalahan yang Ditemukan Setelah Menggunakan Metode Game "tantangan berhadiah point"

\begin{tabular}{lc}
\hline \multicolumn{1}{c}{ Jenis Kesalahan } & Prosentase Mahasiswa (\%) \\
\hline $\begin{array}{l}\text { salah mengingat dalam menulis nama tokoh sejarah atau nama tempat } \\
\text { dalam sejarah graf }\end{array}$ & 68 \\
\hline $\begin{array}{l}\text { salah dalam menulis simbol derajat dari suatu simpul pada graf yang } \\
\text { diberikan }\end{array}$ & 35 \\
\hline salah dalam memahami konsep derajat suatu simpul pada graf & 18 \\
\hline salah dalam memahami konsep sisi dan simpul pada graf & 18 \\
\hline salah dalam proses berhitung & 15 \\
\hline salah dalam mengingat informasi & 24 \\
\hline
\end{tabular}

\section{Penutup}

Ditemukan ada 7 kesalahan konsep teori graf yang dapat terjadi ketika game "tantangan berhadiah point" diterapkan dalam perkuliahan matematika diskrit dengan tema sejarah dan teori graf. Ketujuh bentuk kesalahan tersebut adalah: (1) Mahasiswa salah mengingat dalam menulis nama tokoh sejarah atau nama tempat dalam sejarah graf sebanyak $68 \%$; (2) $35 \%$ mahasiswa salah dalam menulis simbol derajat dari suatu simpul; (3) $18 \%$ salah dalam memahami konsep derajat suatu simpul pada graf; (4) $18 \%$ salah dalam memahami konsep sisi dan simpul pada graf; (5) 15\% mahasiswa salah dalam proses berhitung; (6) $3 \%$ salah dalam mengingat informasi; dan (7) $24 \%$ mahasiswa salah memahami konsep derajat dari graf yang mengandung loop.

Berdasar hasil pengamatan, dan pendapat mahasiswa yang menunjukkan bahwa $88 \%$ mahasiswa memberikan pendapat positif terhadap game ini, walaupun hanya $9 \%$ yang berhasil menjawab sempurna semua soal tes. 
Kesimpulannya game ini tidak menjamin efektifitas perkuliahan namun memberikan suasana belajar yang lebih positif. Dalam hal ini game ini dapat disarankan untuk digunakan dalam tema sejarah dan teori graf, dengan catatan, di pertemuan selanjutnya harus diselidiki dan di perkuat pembelajaran sehingga 7 kesalahan dapat diperbaiki, dan bisa melanjutkan ke tema pembelajaran selanjutnya.

\section{Daftar Pustaka}

Hamalik, O. (2003). Kurikulum dan Pembelajaran. Jakarta: PT Bumi Aksara.

Mardiani, Dian. (2001). Karakteristik Gaya Belajar Matematika Siswa Berprestasi pada Sekolah Menengah Umum di Kec. Depok Kab. Sleman DIY Tahun Ajaran 2000/2001. Skripsi. Universitas Negeri Yogyakarta.

Riswanto, Ari, "Pengaruh model pembelajaran kooperatif tipe team assisted individualization terhadap motivasi belajar mahasiswa". Mosharafa, volume 5, nomor 3, September 2016.

Saepuloh, R, A. (2013). Penerapan pembelajaran sinektik untuk meningkatkan

kemampuan

representasi dan komunikasi

matematis siswa SMP. UPI. Tersedia

http://repository.upi.edu/517/4/T

MTK 1102555 CHAPTER 1. pdf [online, diakses tgl 17 November 2016].

Tim MKPBM Jurusan Pendidikan

Matematika. (2001). Strategi

Pembelajaran Matematika

Kontenporer. Bandung: UPI.

Wahyudi, Sigit. (1995). Peranan Tutorial dan Kemandirian dalam Belajar terhadap Prestasi Belajar Mata Kuliah IImu Alamiah Dasar Mahasiswa Terbuka di Unit Program Belajar Jarak Jauh Yogyakarta. Skripsi. IKIP Yogyakarta.

\section{Riwayat Hidup Penulis}

Dian Mardiani, M.PMat.

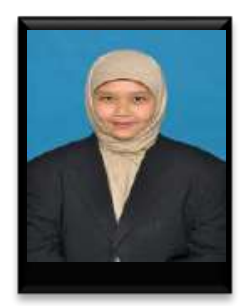

Lahir di Garut, 30 Oktober 1978. Staf pengajar di STKIP Garut. Studi S1 (Bidang Pendidikan Matematika) (UNY), (Yogyakarta), lulus tahun (2002); S2 (Bidang Pengajaran Matematika) (ITB), (Bandung), lulus tahun (2011). 
This page is intentionally left blank 